University of Nebraska - Lincoln

DigitalCommons@University of Nebraska - Lincoln

Displaced Spanish men: Masculinity, sexuality, and migration in Hemos perdido el sol (1963), by Ángel María de Lera

Iker Gonzalez-Allende

Follow this and additional works at: https://digitalcommons.unl.edu/modlangspanish

Part of the Spanish Literature Commons

This Article is brought to you for free and open access by the Modern Languages and Literatures, Department of at DigitalCommons@University of Nebraska - Lincoln. It has been accepted for inclusion in Spanish Language and Literature by an authorized administrator of DigitalCommons@University of Nebraska - Lincoln. 


\title{
Displaced Spanish men: Masculinity, sexuality, and migration in Hemos perdido el sol (1963), by Ángel María de Lera
}

\author{
Iker González-Allende
}

Department of Modern Languages and Literatures, University of Nebraska-Lincoln, Lincoln, Nebraska, USA

Corresponding author - Iker González-Allende, igonzalezallende2@unl.edu

\begin{abstract}
This article analyzes the interconnections between masculinity and migration in the work Hemos perdido el sol, by Ángel María de Lera. The novel depicts the challenging experiences of Spanish migrants in Germany in the 1960 s and the different conception of gender between Spanish and German cultures. The impact of migration on the main character's masculinity is threefold. First, migration enhances his traditional sense of masculinity as he escapes poverty and subsequently feels more respected as a man when he achieves economic independence. Secondly, migration negatively affects his masculinity through the insecurities and discrimination he endures abroad. Lastly, although he adjusts his conventional male behavior at the beginning of his extramarital relationship with a German woman, his understanding of virility remains unaltered and he soon restores his traditional Spanish masculinity. The final message of the novel is that Spanish men's relationships with German women are not meant to be successful due to cultural differences and divergent gender models.
\end{abstract}

Published in Romance Quarterly 2019, vol. 66, no. 4, pp. 205-217.

doi 10.1080/o8831157.2019.1684091

Copyright (C) 2019 Taylor \& Francis Group, LLC. Used by permission.

Published 12 November 2019. 
ender and sexuality are key factors to understanding the expe-
rience of migration, while migration can also affect a person's sense of gender and sexuality practices. As Eithne Luibhéid claims, it is necessary to carefully consider the categories of gender and sexuality to properly analyze any type of displacement (171). Until the 1970 s and 8os, gender was not deemed relevant in migration studies, and scholars generally addressed migrants only as males-but men without a gender and a sexuality-focusing on their economic challenges and adaptation to a new country. Since then, to change this limited perspective, the experiences of migrant women have been explored in multiple works. Only in the last decade have scholars such as Mike Donaldson, Lionel Cantú, Ernesto Vásquez del Águila, and Héctor Carrillo focused on the gender and sexuality of migrant men. These studies illustrate the importance of examining displaced men as men, that is, as individuals with a gender and sexuality, in order to explore how their masculinity and identity are affected by their migration when facing the difficulties of displacement, a new culture, and a new conception of gender in the host country.

After migration, it is common for men to experience changes in both their gender performance as men and their understanding of gender roles. Each migrant man faces his migration process in an unique and different way, and his masculinity is distinctly impacted as well. Scholars such as Mike Donaldson, Richard Howson, and Bob Pease emphasize the feeling of powerlessness and emasculation that migrant men suffer (Donaldson and Howson 211; Pease 80). This does not mean that these men do not continue to enjoy the privileges derived from the patriarchal system in the host country. However, the discrimination and insecurity they often face tend to have a negative effect on their sense of masculinity. ${ }^{1}$ Migrant men may also endure strenuous working situations that involve performing work beneath their skill levels, or, on the contrary, they may improve their economic status and gain fulfillment from being able to provide for their families.

The impact of both discrimination and economic improvement on migrant men's masculinity appears very clearly in the novel Hemos perdido el sol, published in 1963 by Ángel María de Lera. This work reveals the challenging experiences of Spanish migrants in Germany in the 196os, as well as the stark differences in the conception of gender between Spanish and German cultures. Migration enhances the traditional sense of masculinity of the main character, Ramón Peña, 
because he escapes his poverty-laden past and achieves economic independence, thereby feeling more accomplished as a man. However, migration also negatively affects his masculinity through the insecurities and discrimination he endures abroad. Although he adjusts his conventional male behavior at the beginning of his extramarital relationship with a German woman, his understanding of masculinity remains unaltered. In fact, he soon restores his dominant attitude and embraces traditional Spanish masculinity in order to feel rooted and

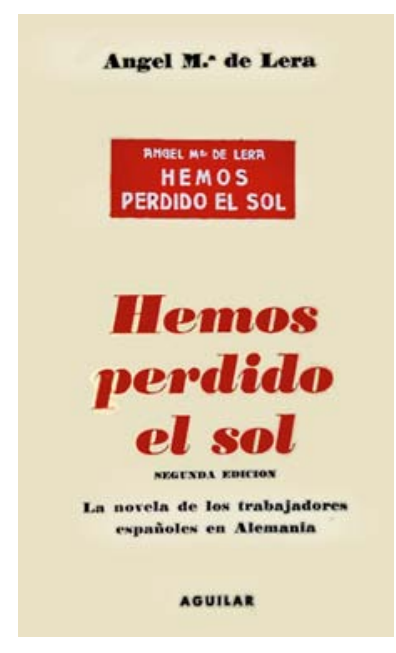
as a sign of national pride. When he decides to end his relationship with his German girlfriend and reunite with his Spanish wife, the novel argues that Spanish men's relationships with German women are not meant to be successful due to cultural differences and divergent gender models.

The main character embodies a "marginalized masculinity" both in Spain and in Germany. R. W. Connell coined this term to refer to the masculinity of those men who, due to their lower social class and/or non-white race, remain on the margins of masculine power in society (Masculinities 80). This is Ramón's case in Spain due to his lack of capital and struggle to earn a living as a working-class man. In Germany, even though he improves his economic condition, he continues within this realm of marginalized masculinity because he is discriminated against based on his race and national origin. Although Connell does not mention migration or foreign status as one of the personal traits that causes marginalized masculinity, it is undoubtedly another key facet of identity that disadvantages men in a given society. Thus, Ramón remains distant from hegemonic masculinity, which is the most exalted type of masculinity that only a minority of men in society embody, the ones on the top of the hierarchy of masculinities (Connell and Messerschmidt 832). However, his traditional understanding of gender epitomizes a "complicit masculinity" because, even though he does not enact hegemonic masculinity, he supports its values and benefits from patriarchy (Connell and Messerschmidt 832).

Ramón's story showcases the most important Spanish migratory movement of the twentieth century, motivated by the poor living conditions, low salaries, and lack of job opportunities existing in Spain 


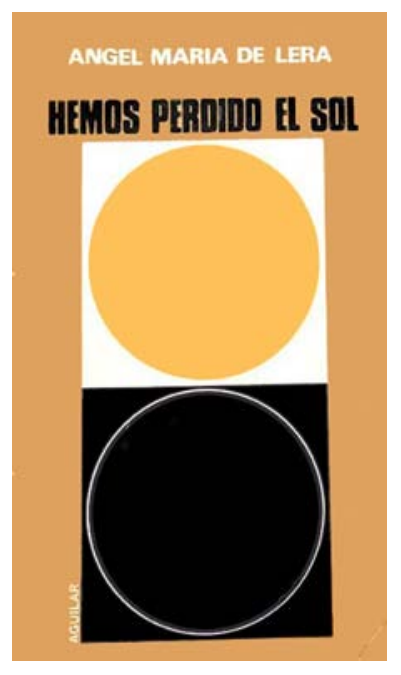

in the 196os (Santos 32). More than two million Spaniards moved to other European countries-mostly Germany, France, Switzerland, Belgium and Great Britain-to earn more income for themselves and their families. In Spain, the majority of these migrants had worked in construction, manufacturing, and agriculture, and as Antonio Muñoz Sánchez states, their objective when moving to the new country was to save money and later come back to Spain to live comfortably (32). The remittances they sent to their relatives in Spain helped improve the battered Spanish economy. Furthermore, their migration benefited Franco's dictatorship by alleviating social tensions caused by unemployment, strikes, and workers' movements from the countryside to the cities. In this regard, Félix Santos considers that this migration was in many cases more favorable for the host and home countries than for the migrants themselves (32).

Hemos perdido el sol is one of the most relevant novels about the 1960 Spanish migration due to the diversity of characters and situations included in its 449 pages. The text opens with the arrival of a group of Spaniards at a German train station, where Ramón is separated from his wife, Paulina, who is sent off to work in Munich while he is destined for Hamburg. Ramón and Paulina remain apart for eight months, while their three-year-old son stays in Spain with Paulina's parents. Both characters live in the same-sex dormitories provided by the factories that employ them and share their rooms with fellow Spaniards whose stories are also included in the narration. Paulina's manager, Georg, falls in love with her and unsuccessfully tries to court her, while Ramón begins a relationship with a German woman, Marleen. Ramón increasingly shows less interest in Paulina and delays answering her letters, so she finally resolves to travel to Hamburg and visit him without previous notice. When Paulina arrives at Ramón's house, he decides to end the relationship with Marleen and recommit to his marriage.

The novel is based on the author's conversations with Spanish workers in Germany. The German government invited Lera to visit the country in 1962, and the following year the newspaper $A B C$ 
commissioned him to write a series of articles about Spanish migrants, which he later developed and published in a book entitled Con la maleta al hombro (1966). Several of the stories narrated in Con la maleta al hombro were first included in the novel. Lera believed that this migration was the most important social event in Spain since the Spanish Civil War and that his responsibility as a writer was to bear testimony to the people affected by it (Con la maleta 13, 16). As this novel shows, he was

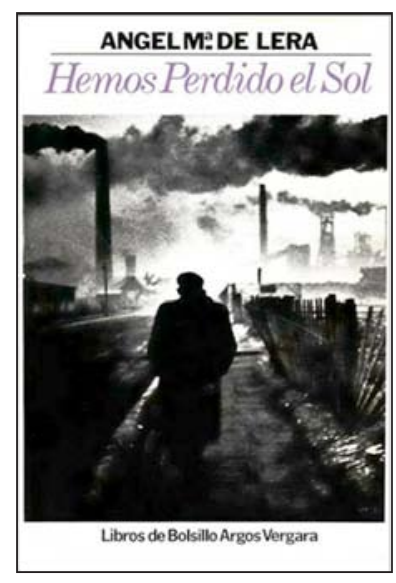
very critical of the causes and negative consequences of this migration and complained about the Spanish government letting valuable, hardworking people emigrate instead of using their talents to further develop Spain (Con la maleta 207).

The social component in Lera's works connects him with the socalled Generation of '50 in Spain, although he belongs chronologically to a previous group of Spanish writers, the Generation of '36 (Leeder 17; Castro Díez 26-27). Lera published his first novel in 1957, at the age of 45 . He had been incarcerated for fighting on the Republican side during the Spanish Civil War, his death sentence commuted to an eight-year prison term. He held multiple jobs after imprisonment and struggled to subsist, unable to find time to write until later in life (Listerman 3). His political commitment and personal struggles influenced his works, which revolve around social and existential themes including loneliness, suffering, and alienation (Castro Díez 11). These topics are common in the social realist novel of the $1950 \mathrm{~s}$ and 60 by authors such as Miguel Delibes, Jesús López Pacheco, and Jesús Fernández Santos.

As a writer and journalist, Lera published numerous books, won several literary prizes, reached a wide mass of foreign readers through translations, and had several of his novels adapted to the Spanish screen. Despite this success, especially with his novel Las últimas banderas (1967), which depicts the losing side in the Spanish Civil War, his works have barely received critical attention in recent times. María Asunción Castro Díez explains this oversight due to the themes and style of his novels: the use of melodrama and social realism, the focus on the society of his time, and the lack of innovative narrative techniques (30). A similar outcome occurred with other Spanish authors 
who wrote novels about the Spanish migration to Germany in the 196os, such as Rodrigo Rubio with Equipaje de amor para la tierra and José Martín Artajo with La desaparición de Porfiria Santillana (Rodríguez Richart 359). ${ }^{2}$ Nevertheless, these works, and Hemos perdido el sol in particular, are essential for studying the challenges and opportunities that Spanish migrants experienced in other countries and for gaining a better understanding of the history of Spanish migration.

\section{Working-class masculinity and economic improvement}

Hemos perdido el sol is also a critical text for delving into the connection between migration and masculinity. Ramón embodies traditional masculinity common to the Spanish society and the working class of the 196os. When analyzing working-class men, scholars usually emphasize that they are conservative in gender politics because of the importance they confer to the heteronormative family and their roles as economic providers. R. W. Connell explains that the family offers working-class men economic and emotional support against the pressures of the labor market (The Men 107). Lera expresses the same idea when discussing how the family and home make migrant men feel important, validating their masculinity: "El hombre, tal vez, no tenga muchas cosas que decir, pero al sentarse entre los suyos, comprueba que hay reverencia a su alrededor. [...] él es el centro, el juez, la providencia. Allí es importante" (Con la maleta 83).

For this reason, Ramón struggles when his wife is separated from him in the train station. The separation from her makes him feel lonely and insecure, like a failure for not being able to protect her. When he emphatically requests at his factory that his wife be transferred to Hamburg, he is told that living away from one's spouse is not a serious problem (44). Paulina receives a similar answer when she asks for help: "Esta gente no le da tanta importancia como tú y como yo al hecho de que un matrimonio viva separado por razones de trabajo" (98). This demonstrates the different conception of marriage between Germans and Spaniards, as well as their divergent understanding of masculinity.

Ramón's sense of masculinity heavily relies on his role as a father and provider for his family. For him, having children is a source of pride. Paternity has traditionally been considered an indication of 
virility. Ernesto Vásquez del Águila points out that becoming a father allows men to validate their masculinity and heterosexuality (114). Ramón believes that it is natural that married couples have children, while, in contrast, Hans, his German coworker, and his wife, Margot, prefer enjoying life on their own: “¿Niños? No, no. Estorban ahora. Nosotros, jóvenes. Próximo año ir por vacaciones a España” (53). Throughout the novel, German society is depicted as one where children are not a priority for married couples and, in fact, are considered a nuisance. Ramón realizes this when searching for an apartment to rent and the landladies he speaks with reject him as soon as he discloses that he has a child.

Fatherhood implies more responsibilities for Ramón since he follows the traditional belief that a man needs to earn money and provide for his wife and children. Tina Miller writes that breadwinning has usually constituted a defining feature of "good fathering" (44). However, Ramón is unable to maintain his family due to the low salary he earns in Spain working in a printing house. As a consequence, he starts feeling like a failure, which affects his masculinity: "una madurez prematura sombreó el rostro y el carácter de Ramón. Se hizo más callado, más pensativo. [...] Las estrecheces económicas [...] alcanzaban ya a la carencia de lo indispensable" (120). Although he begins to work a second job, his family's economic situation does not improve and he becomes more resentful. It is then that he decides to move to Germany as his last resource: "Aquí todo es para ellos, para los patronos; para nosotros, nada. [...] Ellos se hacen ricos, mientras nosotros no podemos vivir...Yo ya no resisto más” (121).

Ramón's frustration and emasculation because of his inability to play the role of the provider reveal the impact of work on men's masculinity. Men may feel anxiety when they are unable to maintain their families (Vásquez del Águila 99). In fact, when Ramón remembers the poverty he endured in Spain, he connects it with a sense of worthlessness: "No poder comprar más que cigarrillos sueltos, jamás un paquete entero; volver a las once de la noche, deshecho; no tener esperanza, a pesar de que en casa todos me miraban esperando algo... [...] Yo no valía para nada, ¿comprendes?” (403). Ramón also emphasizes the expectations of his family, a common situation in unemployed men, who can see their wives as a source of pressure rather than support (Willott and Griffin 115). He seems to feel this way about Paulina, who is constantly complaining that she needs more money to pay for 
the family's daily expenses: "Si vieras cómo sube todo de precio, día a día ... Te digo que daría no sé qué por no tener que ir al mercado. ¿Has hecho horas esta semana? Pues, hijo, no sé ... Con el oficio que tú tienes ... Te advierto que yo no sé hacer milagros, ni de un duro seis pesetas" (437). Paulina's reproach to Ramón for the lack of money affects his masculinity and self-worth.

Migrating allows Ramón to improve his economic situation and save a fair amount of money while working in a German factory. In addition to earning a higher salary, the better working conditions make him feel more appreciated: "Aquí, el trabajo es la única categoría y la única recomendación. Todo el mundo trabaja” (186). Several male characters point out that in Germany they are treated with respect in the workplace. For instance, Fernando mentions that in Spain day laborers have to beg for work, while in Germany bosses work as much as their employees (230). Ramón also admits that he was unable to enjoy life until he came to Germany and started earning more money: "Yo no he empezado a vivir hasta ahora. Nunca había bebido champaña, ni comido en restaurantes, ni bailado en cabarets, ni paseado en coche" (318). The purchase of new clothes makes him feel more secure and self-confident since he no longer stands out for wearing his old Spanish garments.

However, the most significant economic improvement for Ramón happens when he leaves the communal dormitory and move to his own house. Back in Spain, he and Paulina lived with Paulina's parents, so he never experienced living independently. For Ramón, lacking a place of his own implies status of "a half man": "no soy más que un medio hombre porque me falta lo principal para serlo completamente: una casa propia" (243). From his point of view, a house is a symbol of a man's autonomy and the place where he can exert his control: "No serás verdaderamente un hombre libre hasta que no tengas un cobijo propio. Lo primero que el hombre necesita es poder cerrar una puerta y decir: ‘Aquí mando yo!’ (232). As Willott and Griffin state, for a man the home traditionally represents "his castle and a place of privacy," away from the world outside (120).

For this reason, when his German teacher helps Ramón find a shack in which to live, even though it is small and modest, he considers it an important achievement: "Dejaré de ser huésped por una vez en mi vida" (352). He even writes "Spaniard" under his name on his identification card and places it on the exterior of the shack, which shows 
his patriotic pride in connection to the accomplishment of having a place of his own. He does not accept Marleen's money to pay for the furniture because he considers economic independence a core value of masculinity.

\section{Discrimination, emasculation, and protest masculinity}

Despite his economic progress, Ramón and other male characters experience numerous situations in their daily lives that negatively affect their masculinity. Spanish migrant men sometimes suffer discrimination and are mistreated by Germans and other times the new environment makes them feel insecure and they display behaviors that have traditionally been considered non-masculine, such as fear and lack of confidence. This is supported by Cristina Alcalde's claim that migration can destabilize men's power and cause feelings of helplessness and vulnerability (456). In Con la maleta al hombro, Lera also underscores the lack of confidence migrant men experience: "La sensación de impotencia y de inferioridad no abandona nuestro ánimo [...] la vida circula alrededor de nosotros, pero como una corriente que nos margina, convirtiéndonos en un islote solitario" (33).

The hardships migrant men endure are reflected in the title of the novel, where the sun that Spaniards have lost in Germany symbolizes not only Spain's warm weather, but also their home and family, and Spaniards' jovial character. In opposition, Germany is connected to the snow, cold climate, and unfriendliness: “¿Es que se puede vivir a gusto en un país como este, donde no se ve el sol ni por casualidad?" (37). Lera continues using this image in Con la maleta al hombro, where he calls Spaniards "los hijos del sol” (118). With this symbol, the author not only reproduces national stereotypes that may not be always true, emphasizing a nostalgic patriotism, but he also overlooks a positive outcome for Spanish migrant men in the novel: gaining economic stability and masculine capital.

Related to this lack of sun are the tendencies of several male characters to be homesick, miss their families, and remember their good times in Spain. Eduardo and Lucio, who live in the same dormitory as Ramón, like to indulge in an idealization of what they left at home, thinking of their relatives and listening to Spanish news and music on the radio. This emotional behavior conflicts with normative 
masculinity, which, as Victor Seidler explains, is based on strength and the control of emotions and feelings (90). Ramón demonstrates this masculine trait when he accepts his new situation in Germany with stoicism and confronts Eduardo and Lucio for being nostalgic for a country that dismissed them: "Estamos en Alemania, ¿no? ¿Y por qué? Porque en España no tenemos sitio. Nos echaron de allí, como quien dice" (85).

Nevertheless, there are moments when Ramón reveals insecurities that undermine his wished resilience. At the beginning of his time in Germany, he is self-conscious when he thinks that Germans on the street are laughing at him. Additionally, his difficulties understanding and speaking the language make him feel isolated, invisible, and frustrated when he is around Germans: "No se han dado cuenta de que existo yo y de que estoy aquí. No les importo lo más mínimo. Y aunque les importara, ¿qué podrían decirme? ¿Qué podría decirles yo? Si me uniera al grupo, ¿cómo nos entenderíamos? Imposible. Este endiablado idioma nos separa" (148-49). ${ }^{3}$

A new and unfamiliar environment and different societal rules in the host nation may also cause migrant men to overreact and behave in irrational and childlike ways. As David Gilmore claims, men achieve masculinity by overcoming childhood (29) and, therefore, infantile behavior undermines their virility. This was the case of Spanish migrants who, according to Lera in his trips throughout Germany, magnified small problems that, back in Spain, they would have considered insignificant:

[n]o cabe duda que todo hombre, al ser transplantado tan bruscamente a un país cuyo idioma, costumbres y clima le son desconocidos, se infantiliza. Tiene que empezar por aprender cómo se llaman el pan y el agua, a qué hora se come, cómo adaptarse a las nuevas temperaturas...[...]. Los hombres andan como extraviados en un laberinto, hiriéndose en incontables encontronazos. (Con la maleta 38-39)

The character who most clearly shows the negative consequences of migration on men's mental health is Eleuterio, a Spanish man whom Ramón finds talking to himself in the streets of Hamburg. Eleuterio displays fear, distrust and signs of psychosis after running away from a German farm where he was working and living for three months, 
with no communication with the farm owners or friendly gestures from them: "Lo de comer solo, como un perro, me mataba. Y me mataba más el oírles hablar en mi presencia como si yo no existiese" (247). Mental illness was not uncommon among Spanish migrant men, as Víctor Canicio narrates in Vida de un emigrante español (1979) (González-Allende, “The Migrant” 143). Nervous breakdowns or madness undermine these men's masculinity, since, according to Timothy Beneke, men are traditionally supposed to endure stressful situations, both physically and emotionally (36).

If life in the host society can sometimes induce self-doubt and moments of crisis in migrant men, on other occasions, exploitation and mistreatment by the host society are the main causes of their feelings of emasculation. In Lera's novel, a significant episode in this regard happens to Lucio, who loses his hand to a hammer while working in a factory and will be sent back to Spain because he is no longer able to work (435). His stump is a symbol of castration, of the physical loss and mental sacrifices that Spanish men endure in Germany. Although in the novel there are rarely complaints about migrants' working conditions, this event shows the labor exploitation of Spanish migrants and Germans' lack of compassion toward them. When Lucio is injured in the factory and the other Spaniards stop working to see what happened to him, the German manager urges them to return to work, proving that Spaniards are solely considered to be expendable labor.

In their daily lives, migrants also experience discrimination from Germans. For instance, when the Spanish men are traveling by train to Hamburg, a German passenger enters their carriage and makes a facial expression of disgust when he sees them (31). Another character mentions that in certain German bars the entrance of Spaniards is prohibited (73). In his conversations with Spanish migrants, Lera confirms the Germans' disdain: "En principio nos miran a todos por encima del hombro y pretenden que no olvides dos cosas: que ellos son alemanes -que es lo más que se puede ser-y que tú eres latino -que es tanto como decir que perteneces a unas razas decadentes-, y que ellos están en su casa y que tú eres el huésped" (Con la maleta 185).

Ramón is also the target of xenophobia when he looks for apartments and the landladies ask him whether he is Turkish, Persian, or Italian, labeling and stereotyping him according to his features. These constant rejections make him feel frustrated and emasculated. He is 
also mistreated when he visits his coworker Hans's apartment, and his wife Margot starts touching and kissing him, which causes him to feel uncomfortable. Margot assumes Ramón is a passionate man because he is Spanish, objectifying and taking advantage of him. Her behavior exemplifies how women can exoticize migrant men, finding them attractive based on cultural stereotypes. In this regard, Paul Crossley and Bob Pease state that in host nations, Latino migrant men are usually perceived as more chivalrous and passionate but not as potential partners for a serious relationship (126).

At the end of the novel, Margot continues to show interest in Ramón, which causes Hans to go to Ramón's shack and challenge him to a fight. This episode is based on a true event that Lera narrates in Con la maleta al hombro, where a Spanish man was actually having an affair with the wife of a German man, and the German attacked the Spaniard with a knife (124-25). Lera changes this in the novel so that the Spanish character appears as physically strong and victorious and at the same time is not seen as deserving of his opponent's attack. Indeed, Ramón resorts to violence only to defend himself from Hans's aggression. The fact that Hans calls him "asqueroso español” (405) before entering the shack gives this fight a patriotic component. Ramón is not only defending his masculinity, but also his nation and Spanish identity.

Migrant men may react with violence when they feel disrespected in a host nation or as compensation for the exploitation and discrimination they suffer in their workplace and daily lives. This type of behavior has been labeled "protest masculinity" (Broude 103) and is the result of the feelings of impotence men experience due to social status, race or national origin. Thus, when men lack economic or social power, they may behave in an aggressive way to prove they are still masculine. ${ }^{4}$ Ramón displays this type of conduct in different instances. For example, in the factory where he works, he raises his voice and punches a tabletop because the managers refuse to transfer Paulina to Hamburg: "Rafa se unió a Antonio para contenerlo [a Ramón] y Ramón quedó frente a la ventanilla, rojo de indignación, temblando, resollando fuertemente" (44).

Ramón also shows his anger when, in his search for an apartment to rent, he suffers discrimination: “A Ramón le sacudió un ramalazo de ira. [...] Cerró los puños con rabia y alzó uno en el aire. Temblaba todo él" (147). Lera himself acted in a similar way when he was in 
Germany and felt mistreated by a German railway worker who, instead of helping Lera find the train he had to take, showed disdain for his Spanish identity: "hizo un gesto de desdén y me volvió la espalda, murmurando: ‘¡Oh, español!’. [...] Comencé a vociferar y a insultarle con el más selecto vocabulario ibérico. Por supuesto, el tipo aquel no se dio por enterado, y eso me irritó aún más” (Con la maleta 35).

Ramón encourages his compatriots to be tough and to fight through adversity and discrimination in order to find a place in Germany: "si tu mujer se fuera con otro, ¿qué harías? ¿Estarías todo el día hablando de ella, o procurarías olvidarla y buscarte otra? Este es el caso nuestro ahora. Tenemos que conquistar un sitio en este país" (86). By identifying the nation with a woman, Ramón uses a traditional rhetoric in nationalism and links Spanish men's migration to a sexual conquest, that is, considers their adaptation and economic success as a victory and proof of masculinity. Ramón's last name, "Peña," seems symbolic in this way, since it could indicate his persistence, his ability to be firm and overcome the problems of migration.

Ramón connects this resilient attitude with the Spanish custom of bullfighting, considering himself a bullfighter who must surmount hardships in Germany. With this symbol, he encourages himself and finds pride in his national culture and traditional Spanish masculinity: “Tampoco el torero quisiera enfrentarse con los cuernos del toro, pero tiene que decidirse entre ellos o el hambre" (222). Ramón even employs the image of bullfighting to comment on a friend's relationship with his girlfriend: "veo que el toro te cogió bien por la faja" (327). By identifying a woman with a bull, he reveals a traditional understanding of love as a fight in which men need to control women. ${ }^{5}$

This chauvinistic conception of love appears when Ramón uses violence against Marleen because he thinks she has been unfaithful: "Marleen recibió las dos bofetadas de refilón, sin tambalearse siquiera" (439). This reaction, caused by anger and frustration, is another example of Ramón's protest masculinity, which, as Raymond Hibbins and Bob Pease note, may take the form of domestic violence against women (2-3). Ramón slaps Marleen to show his dominance and feels more powerful and masculine. Alcalde also points out that the violence migrant men exert over women can serve as a signifier of their masculinity (459). In these situations, as Pierrette Hondagneu-Sotelo and Michael Messner claim, it is important to consider that migrant men may be violent against women not only as a liberation from their 
societal oppression, that is, as an expression of protest masculinity, but also as a result of their misogyny and the social prevalence of patriarchy (208).

\section{Sexuality and maintenance of traditional masculinity}

Ramón's traditional conception of gender does not significantly change during migration, even though he slightly modifies his regular behavior by doing some chores in the residence and by paying more attention to his physical appearance. At the beginning of his relationship with Marleen, he also adopts a more passive role, but soon after takes the lead and tries to dominate. A migrant man's change of behavior does not necessarily mean a variation of his mentality or of his sense of masculinity. ${ }^{6}$ Pease confirms that most migrant men who abandon patriarchal attitudes have been forced to do so and reject any alteration of their gender ideology (94). ${ }^{7}$ For instance, although Paulina is also working in a factory, Ramón admits that he would prefer to have his wife at home to take care of him and their child: "Mi mujer, por ejemplo, trabaja ahora por una circunstancia muy especial. Pero si viviéramos normalmente, yo prefiriría que ella estuviese en casa, para cuidar del niño y de mí” (341).

In Germany, Ramón and the other Spanish men have more opportunities to engage in sexual adventures because of the more liberal understanding of sexuality in comparison to Spain's traditional morality. ${ }^{8}$ Rafa explains it this way: "Aquí al menos tienes donde elegir. Mal que bien, puedes desahogarte de cuando en cuando. Pero ¿qué podía hacer yo en Madrid? La última vez me tuve que ir con una fulana que encontré en los alrededores de Tirso de Molina. Era un pingajo" (163). As Vásquez del Águila contends, migration "expands the possibilities for new forms of intimacy and sexual encounters" (190). Being away from home, their wives and relatives, migrant men have more freedom to experience their sexualities. ${ }^{9}$

As a result of this distance, Ramón starts a relationship with Marleen after they meet in a nightclub. He does not seem to feel remorseful about his affair, stating that he needs to seize the opportunity to spend time with such a beautiful woman. It is not uncommon for married migrant men who live far away from their wives to engage in sexual affairs or romantic relationships in the host country. They 
usually argue that the extramarital relationship is a consequence of their loneliness and sexual needs. Vásquez del Águila points out that migrant men also tend to think that it is acceptable to be unfaithful to their wives, though they still expect their wives to remain loyal to them (198). Even people in the home nation allow for infidelity in migrant men if they are still responsible and provide for their families (Vásquez del Águila 112).

In the novel, Spanish women are also permissive of their husbands' affairs. Paulina thinks that Ramón will not be able to stay without a woman for a long time (188), while Amparo expresses a similar idea: "Pero los hombres no pueden aguantarse como nosotras y en cuanto ven unas caderas moviéndose, pierden el conocimiento" (366). At the end of the novel, when Paulina appears unexpectedly in Ramón's shack, she decides to ignore the presence of Marleen's clothes and acts as if they are still happily married. Not only does Paulina forgive Ramón's adultery, she considers it logical and does not even ask him for any explanation.

Both male and female Spanish characters follow a traditional conception of male sexuality, which Ken Plummer has called "hegemonic male sexuality": the belief that men's sexuality is "powerful, natural, driven" and uncontrollable (178). Thus, Ramón stares at women on the street, Lucio has sexual encounters with a Spanish prostitute, and Rafa is desperately looking for women. In Con la maleta al hombro Lera also seems to justify Ramón's adultery when he explains that married men who live alone in Germany feel incomplete without a woman and, therefore, tend to find a lover:

nuestro emigrante es un hombre incompleto. Y, además, un hombre torturado porque su edad y los hábitos eróticos adquiridos en el matrimonio [...] han contribuido a la irrenunciabilidad del ejercicio sexual. Aparte del cilicio de la abstención a rajatabla, solo dos soluciones se le ofrecen a nuestro hombre: la aventura ocasional con la mercenaria o el entendimiento estable y discreto con la no mercenaria. (87)

At the beginning of his relationship with Marleen, Ramón has to adapt to the more egalitarian gender roles in Germany. In the novel, there are many references to the freedom of German women in comparison with Spanish women. From the Spanish characters' 
perspective, German women behave the same as men do in Spain. ${ }^{10}$ Ramón experiences this situation the first night he meets Marleen. She is the one who takes him out to dance, decides to bring him to her apartment in her car and leads their sexual encounter: "Ramón, obnubilado, se dejó llevar sin resistencia, prendido por la mano” (173). Ramón feels self-conscious because he thinks that Marleen is too attractive for him and she is the one who makes the decisions in the relationship: "Es ella la que lleva la batuta. ¿Por qué no quiso que nos viéramos hoy? ¿Es que tendrá otro tío?” (228).

However, soon after, Ramón starts acting in a more traditional and dominant way. He shows signs of jealousy, slaps Marleen on one occasion, makes her wait in her apartment on Christmas Eve, and despite Marleen's insistence, he does not reveal their relationship to Paulina. Marleen starts becoming emotionally dependent on Ramón, discloses her loneliness and her traumatic past when she was raped at eleven years old and even exclaims she wants to have a baby with him. The restoration of Ramón's traditional male behavior proves that he never really changed his understanding of masculinity and that at the beginning of his relationship with Marleen, he was acting differently because it was his first time being with a German woman. Ramón embraces traditional Spanish masculinity to feel grounded and achieve continuity in his life in the midst of multiple changes caused by migration.

Although Marleen adopts a more submissive attitude, their relationship is not meant to have a future. In Con la maleta al hombro, several Spanish men tell Lera that marriages with German women would be complicated due to their cultural differences: “¿Cómo casarse con una persona a quien no se puede conocer a fondo? Es creyendo que se la conoce y luego se lleva uno cada chasco ... Mire, son muy diferentes, en todo, a nosotros” (101). Ramón also warns Rafa about marrying Bárbara, his German fiancée: “te encontrarás con el problema de tener que consentir a tu alemana muchas cosas que no consentirías a una española" (328).

One of the primary cultural differences between German women and Spanish men involves childbirth: German women are portrayed as not wanting to or not being able to have children. When Bárbara becomes pregnant with Rafa's child, she decides to secretly have an abortion because she thinks it is not the appropriate time for them to 
be parents. When Rafa is told about the abortion, he feels frustrated and emasculated: “¿Por qué no me lo dijiste? ¿Es que yo no soy nadie? Soy tu novio y el padre" (427). ${ }^{11}$ In another example, Marleen reveals to Ramón that, according to her doctor, she is unable to have children (409). In contrast, Catalina and Antonio, two Spanish migrants, are about to have a child. This difference in the concept of family is one of the chief reasons that Lera offers for the impossibility of a successful union between Spanish men and German women.

The novel also reveals that German women's independence and equality with men causes suffering for German men. Margot's affairs with other men make Hans feel insecure, but they continue their marriage. For Ramón, Hans's permissive behavior with his wife is emasculating. As Pease notes, it is common for migrant men to believe that men are being dominated by women in countries with more egalitarian gender roles (89). Another German man, Georg, tries to court Paulina because he likes Spanish women's modest attitudes that German women have lost: "Nuestras mujeres son hermosas, qué duda cabe, pero han perdido mucho encanto. No quieren más que libertad. [...] Mis amigos no son felices con unas esposas que hacen vida de hombres" (195). ${ }^{12}$ In this regard, the novel conveys a conservative message in favor of traditional gender roles for both women and men, while Spaniards and their culture are depicted more positively than Germans. ${ }^{13}$

When Paulina appears unexpectedly in Ramón's shack, he decides to end the relationship with Marleen. Paulina praises the decoration of the house, mentions a new bed for their child and is understanding of his love affair. It is then Ramón realizes that he has forgotten his role as a husband and father and needs to recommit to his family responsibilities. Thus, his relationship with Marleen is not meant to be: "Sí, muy hermosa [...] Como tantas otras cosas de esta tierra, que no son para nosotros" (449). Finally, Ramón decides to follow Lucio's advice: "Tráete a tu mujer y al chico como sea. [...] Hazme caso. No hay nada como la familia, como la propia sangre. [...] Por fuera lo de aquí; por dentro, lo que mamamos, lo que trajimos" (433). With this ending, in addition to expressing a patriotic message about maintaining Spanish customs and gender systems, the novel proposes that Spanish men's traditional masculinity is incompatible with romantic relationships with German women. 
Hemos perdido el sol bears testimony to the hardships and sacrifices of Spanish workers, as well as the challenges they encounter in German society. The novel has a clear social component, in common with other social realist works of the 196os, and aims to shed light on the Spanish reader about a reality of that time: the situation of Spanish migrants abroad. Lera offers a positive portrayal of the majority of his Spanish characters and a clear preference for the Spanish culture over the German. In fact, this patriotism, along with the presence of melodramatic episodes, may explain the editorial success of the novel at the time and its subsequent oblivion.

Lera's narrative emphasizes cultural differences between Spaniards and Germans, especially their opposite understanding of family, gender, and sexuality. Ramón embodies traditional masculinity typical of 1960 spain, based on the formation of a heteronormative family, the breadwinner role, and the conception of male sexuality as driven and difficult to control. However, his working-class background and the difficulties he experiences providing for his family position him far away from the hegemonic masculinity he aspires to achieve. For this reason, he decides to migrate, to be able to abandon the marginalized masculinity he embodies in Spain because of lack of financial resources. In Germany, his traditional masculinity based on economic independence gets reinforced because, as he earns more money, he escapes poverty and, therefore, feels more respected. Ramón's improved financial circumstances allow him to enjoy life more fully, buy elegant clothes, and reside on his own. However, he continues enacting marginalized masculinity, this time due to his foreign status. As a consequence, he and other male characters experience multiple realities that emasculate them, such as discrimination, racism, work injuries, insecurities for living in an unfamiliar environment and not commanding the German language, homesickness, sexual objectification, and mental health problems. On some occasions, to compensate for this sense of powerlessness, Ramón adopts protest masculinity, reacting in an aggressive way in his workplace, daily life and romantic relationship with Marleen. In this sense, he exemplifies complicit masculinity because, even if he does not enact hegemonic masculinity, he supports its values and benefits from patriarchy.

Although Ramón turns his back on nostalgia and justifies the need to adjust to a new country, his adaptation to Germany does not apply to his conception of masculinity. He and other male characters enjoy 
more sexual freedom and opportunities. This allows Ramón to start a relationship with Marleen, temporarily changing his traditional male behavior by allowing her to take the lead in their encounters. However, when Ramón acquires more economic independence and Marleen shows more emotional vulnerability, he starts dominating their relationship, thus restoring his conservative male conduct. Clearly, Ramón does not support the more flexible understanding of gender roles in Germany and embraces traditional Spanish masculinity as an unchangeable part of his identity. In the end, he decides to recommit to his marriage because his concept of masculinity will work best in a relationship with a Spanish woman, his wife. Ramón's own sense of masculinity and understanding of what a man is and should be never really changed in Germany. His masculinity was displaced and challenged during migration by the society and egalitarian gender roles in Germany, but he counteracted this displacement with the security he experienced in maintaining his original set of traditional Spanish gender values.

\section{Notes}

1. Displaced men, particularly if they have been in a subordinated position in their home countries, may also experience migration in a positive and liberating way when they achieve a greater sense of autonomy and anonymity, and freedom from patriarchy, heteronormativity, and societal expectations about men (Cantú 135).

2. Spanish migrants also published their own experiences in Germany, such as Víctor Canicio, Patricio Chamizo, and Vicente Ballester Gil. Their works, according to José Rodríguez Richart, have a modest literary value but significant testimonial worth (358).

3. Other characters mention similar consequences for not commanding the German language: "Parece que se ofenden si les pregunta uno algo. Claro, contestan en alemán. Uno no entiende, y al insistir, se enfadan” (73).

4. Although the use of the term "protest masculinity" can be helpful in the study of migrant men, it is important to avoid their stigmatization and note that migrant men are not the only ones who embody violent or traditional masculinity (Hondagneu-Sotelo and Messner 208). In fact, there are migrant men who adopt a more egalitarian conception of gender roles (Smith 110), while there are men from the host nation who, without being oppressed by their race or social class, are conservative in relation to gender and behave violently due to patriarchy and hegemonic masculinity. 
5. Despite this traditional Spanish masculinity, in the novel, there is a clear rejection of Spanish migrant men who embody a Don Juan masculinity and are constantly trying to seduce women, such as Luis el Fotogénico. Luis has children with multiple women and tricks Spanish migrant women into leaving their jobs for other positions where they will actually earn less money. His death at the hands of Gonzalo, who kills him for taking advantage of Spanish women, brings poetic justice to the novel.

6. For instance, a migrant man may start taking care of his children or doing housework in the host country because his wife is working outside the home, or a man who migrated alone may have to learn how to do chores, but these new situations for these men may not change their traditional belief that women are mostly responsible for childcare and housework.

7. On the contrary, migration can also make men more open to both accepting new gender models and adopting a more egalitarian understanding of men's and women's roles. In a study about Mexicans living in New York, Robert Smith analyzes the situation of a migrant man who, as a consequence of his migration, adopted a more flexible masculinity, including more active involvement in his daughters' education and more equality in his relationship with his wife (105106). Pease also mentions that in his interviews with migrant men, some of them embraced new gender roles and were pleased that in the host country women had more choices and the same rights as men (91).

8. The topic of unhealthy sexual repression is common in Lera's novels (Listerman 12). According to Castro Díez, in the author's narratives sexuality is depicted as an irrational impulse difficult to control (34).

9. The opposite effect is also possible due to the lack of social networks, racism, and difficult working conditions in the host country. The stress of living in a new country may also cause a decrease in migrant men's libido (González-Allende, Hombres en movimiento 15).

10. In contrast, Spanish women are represented as more naïve and modest. Regina is an exception in the novel because she is unfaithful to her lazy husband, who remains in Spain. However, at the end, Regina's lover dies in an accident, while her husband comes to Germany and tells her that their daughter is going astray. Regina confesses her affair to her husband, their marriage is restored, and then she decides to return to Spain to take care of her daughter. Thus, she goes back to playing a more traditional female role.

11. As Listerman eloquently points out, Rafa's words to Ramón about the abortion-"Lo han deshecho, ¿comprendes? ¡Lo han deshecho!" (429)-could refer not only to the aborted baby, but also to Lucio's lost hand, and even "to all Spaniards who have come into contact with the cold German machine and have lost the sun" (109).

12. A German man expressed the same idea to Lera: "las españolas [...] tienen para nosotros un encanto especial: la coquetería [...]. Las nuestras ya no coquetean: se van derechas al toro, como ustedes dicen" (Con la maleta 121). 
13. Nevertheless, Lera avoids overly simplistic representations of both nations, since there are negative Spanish characters such as Luis and positive German characters such as Georg.

\section{Works cited}

Alcalde, M. Cristina. "Masculinities in Motion: Latino Men and Violence in Kentucky." Men and Masculinities, vol. 14, no. 4, 2011, pp. 450-69.

Beneke, Timothy. Proving Manhood: Reflections on Men and Sexism. U of California P, 1997.

Broude, Gwen J. "Protest Masculinity: A Further Look at the Causes and the Concept." Ethos, vol. 18, no. 1, 1990, pp. 103-22. doi: 10.1525/ eth.1990.18.1.02aooo40.

Cantú, Lionel. The Sexuality of Migration: Border Crossing and Mexican Immigrant Men, edited by Nancy A. Naples and Salvador Vidal-Ortiz, New York UP, 2009.

Carrillo, Héctor. Pathways of Desire. The Sexual Migration of Mexican Gay Men. U of Chicago P, 2017.

Castro Díez, María Asunción. "Introducción biográfica y crítica.” Los olvidados, by Ángel María de Lera, Castalia, 2004, pp. 7-49.

Connell, R. W. Masculinities. U of California P, 2005.

- The Men and the Boys. U of California P, 2000.

Connell, R. W., and James Messerschmidt. "Hegemonic Masculinity: Rethinking the Concept.” Gender and Society, vol. 19, no. 6, 2005, pp. 829-59. doi: 10.1177/o891243205278639.

Crossley, Paul, and Bob Pease. "Machismo and the Construction of Immigrant Latin American Masculinities." Migrant Men: Critical Studies of Masculinities and the Migration Experience, edited by Mike Donaldson, Raymond Hibbins, Richard Howson, and Bob Pease, Routledge, 2009, pp. 115-34.

Donaldson, Mike, and Richard Howson. "Men, Migration and Hegemonic Masculinity." Migrant Men: Critical Studies of Masculinities and the Migration Experience, edited by Mike Donaldson, Raymond Hibbins, Richard Howson, and Bob Pease, Routledge, 2009, pp. 210-17.

Gilmore, David D. Manhood in the Making: Cultural Concepts of Masculinity. Yale UP, 1990.

González-Allende, Iker. Hombres en movimiento: Masculinidades españolas en los exilios y emigraciones, 1939-1999. Purdue UP, 2018.

—. "The Migrant Family Man: Masculinity, Work and Migration in Víctor Canicio's Vida de un emigrante español.” Iberoamericana, vol. 16, no. 62, 2016, pp. $131-47$.

Hibbins, Raymond, and Bob Pease: “Men and Masculinities on the Move." Migrant Men: Critical Studies of Masculinities and the Migration Experience, edited by Mike Donaldson, Raymond Hibbins, Richard Howson, and Bob Pease, Routledge, 2009, pp. 1-19. 
Hondagneu-Sotelo, Pierrette, and Michael A. Messner. "Gender Displays and Men's Power: The 'New Man' and the Mexican Immigrant Man.” Theorizing Masculinities, edited by Harry Bord and Michael Kaufman, Sage, 1994, pp. 200-18.

Leeder, Ellen Lismore. El desarraigo en las novelas de Ángel María de Lera. Ediciones Universal, 1978.

Lera, Ángel María de. Con la maleta al hombro: Notas de una excursión por Alemania. Editora Nacional, 1966.

- Hemos perdido el sol. 1963. Aguilar, 1970.

Listerman, Mary Sue. Ángel María de Lera. Twayne, 1982.

Luibhéid, Eithne. "Queer/Migration: An Unruly Body of Scholarship.” GLQ: A Journal of Lesbian and Gay Studies, vol. 14, no. 2-3, 2008, pp. 169-9o.

Miller, Tina. Making Sense of Fatherhood: Gender, Caring, and Work. Cambridge UP, 2011.

Muñoz Sánchez, Antonio. "Una introducción a la historia de la emigración española en la República Federal de Alemania (1960-1980).” Iberoamericana, vol. 12, no. 46, 2012, pp. 23-42.

Pease, Bob. "Immigrant Men and Domestic Life: Renegotiating the Patriarchal Bargain?” Migrant Men: Critical Studies of Masculinities and the Migration Experience, edited by Mike Donaldson, Raymond Hibbins, Richard Howson, and Bob Pease, Routledge, 2009, pp. 79-95.

Plummer, Ken. "Male Sexualities.” Handbook of Studies on Men and Masculinities, edited by Michael S. Kimmel, Jeff Hearn, and R. W. Connell, Sage, 2004, pp. 178-95.

Rodríguez Richart, José. "Literatura española de tema alemán (siglo XX).” Actas del IX Congreso de la Asociación Internacional de Hispanistas, edited by Sebastián Neumeister, vol. 2, Vervuert, 1989, pp. 351-61.

Santos, Félix. Exiliados y emigrados: 1939-1999. Fundación Españoles en el Mundo, 1999.

Seidler, Victor J. Man Enough: Embodying Masculinities. Sage, 1997.

Smith, Robert. Mexican New York: Transnational Lives of New Immigrants. U of California P, 2006.

Vásquez del Águila, Ernesto. Being a Man in a Transnational World: The Masculinity and Sexuality of Migration. Routledge, 2014.

Willott, Sara, and Christine Griffin. “'Wham Bam, Am I a Man?' : Unemployed Men Talk about Masculinities.” Feminism \& Psychology, vol. 7, no. 1, 1997, pp. 107-28. doi: 10.1177/0959353597071012 